\title{
Healthy gestational weight gain prevalence and associated risk factors: A population-based study in the far South of Brazil
}

\section{Prevalência e fatores associados ao ganho de peso adequado na gestação: um estudo de base populacional no extremo sul do Brasil}

Luana Patricia MARMITT ${ }^{1}$ Carla Vitola GONÇALVES ${ }^{1}$ Juraci Almeida CESAR ${ }^{1}$

\section{A B S T R A C T}

\section{Objective}

To measure and identify the factors associated with healthy weight gain during pregnancy in the municipality of Rio Grande, Rio Grande do Sul, Brazil.

\section{Methods}

This was a population-based, cross-sectional study that included all parturient women from the municipality who gave birth at its maternity hospitals in 2013. Information was collected by interview with the mothers in the first 48 hours following parturition and from the prenatal care cards. Healthy weight gain was evaluated according to the Institute of Medicine guidelines. Data analysis used Poisson regression with robust variance using previous hierarchical model.

\section{Results}

Among the 1,784 pregnant participants, $89 \%$ attended at least six prenatal care visits, and $32 \%$ had healthy weight gain during pregnancy. Higher education level and fewer children resulted in a higher prevalence ratio

\footnotetext{
1 Universidade Federal do Rio Grande, Faculdade de Medicina, Programa de Pós-Graduação em Ciências da Saúde. R. Visconde de Paranaguá, 102, 96200-190, Rio Grande, RS, Brasil. Correspondência para/Correspondence to: LP MARMITT. E-mail: <luanamarmitt@gmail.com>.

Article based on the master's thesis of LP MARMITT, intitled "Ganho de peso adequado na gestação e fatores associados: um estudo de base populacional”. Universidade Federal do Rio Grande; 2015.

Support: Coordenação de Aperfeiçoamento de Pessoal de Nível Superior and Pastoral de Criança de Rio Grande.
} 
for healthy weight gain ( $p=0.003$ and $p=0.029$, respectively). Underweight women at conception had a higher proportion of healthy weight gain $(p<0.001)$. Despite extensive coverage, prenatal care did not affect healthy weight gain during pregnancy $(p=0.104)$.

\section{Conclusion}

The low proportion of women with healthy gestational weight gain suggests a need of better prenatal care services. Women who are overweight, have lower education levels, and had had multiple pregnancies at conception need special attention.

Keywords: Nutritional status. Pregnancy. Risk factors. Weight gain.

\section{R E S U M O}

\section{Objetivo}

Medir a prevalência e identificar fatores associados ao ganho de peso adequado no período gestacional no município de Rio Grande, Rio Grande do Sul.

\section{Métodos}

Trata-se de um estudo transversal de base populacional do qual fizeram parte todas as parturientes residentes no município em questão e que tiveram filhos em maternidades ao longo do ano de 2013. As informações foram coletadas por entrevista nas primeiras 48 horas após o parto e também pelo Cartão da Gestante, usado nas consultas de pré-natal. O ganho de peso adequado foi avaliado conforme critérios do Institute of Medicine. $\mathrm{Na}$ análise dos dados, utilizou-se regressão de Poisson com ajuste robusto da variância e obedecendo modelo hierárquico prévio.

\section{Resultados}

Dentre as 1.784 gestantes incluídas no estudo, 89\% realizaram pelo menos seis consultas de pré-natal e 32\% apresentaram ganho de peso adequado na gestação. Quanto maior a escolaridade e menor o número de filhos, maior a razão de prevalência para ganho de peso adequado ( $p=0,003$ e $p=0,029$; respectivamente). As mulheres que iniciaram a gestação com baixo peso tiveram a maior proporção de ganho de peso adequado $(p<0,001)$. Apesar de ampla cobertura, o pré-natal não se mostrou capaz de influenciar o ganho de peso na gestação $(p=0,104)$.

\section{Conclusão}

A reduzida proporção de mulheres as quais apresentaram ganho de peso adequado na gestação sugere a necessidade de melhoria dos cuidados oferecidos durante o pré-natal. Atenção especial deve ser dada àquelas que iniciam a gestação acima do peso, com níveis mais baixos de educação e de múltiplas gestações.

Palavras-chave: Estado nutricional. Gravidez. Fatores de risco. Ganho de peso.

\section{INTRODUCTION}

Weight gain is a potentially modifiable risk factor during pregnancy'. Its monitoring is a widely used, inexpensive, and very useful procedure to reduce perinatal risks ${ }^{2}$. When appropriate, weight gain during pregnancy reduces the occurrence of fetal macrosomia, surgical parturition, diabetes Mellitus, eclampsia, low birth weight, intrauterine growth restriction, prematurity, and other undesirable outcomes ${ }^{1,3-5}$.

In 2009, the United States Institute of Medicine (IOM) published new guidelines for gestational weight gain taking into account maternal and fetal outcomes during pregnancy and after parturition in order to determine healthy weight gain ranges based on pregestational Body Mass Index (BMI)².

Based on the IOM guidelines, many women in low- and high-income countries are overweight at conception ${ }^{6-8}$, and only one-third has healthy gestational weight gain ${ }^{5,9,10}$. In Brazil a single multicentric cohort study with 2,244 women conducted in four state capitals found prevalences of healthy weight gain in the second and third trimesters of 28.5 and $22.0 \%$, 
respectively ${ }^{11}$. This evidences the difficulty of meeting the weight gain target based on pregestational BMI. Diet, gestational morbidities, attitude towards weight loss or gain, pregestational nutritional status, and maternal education level are among the main determinants of weight variation during pregnancy ${ }^{9,12,13}$.

The use of the current IOM guidelines for the assessment of healthy gestational weight gain in Brazil involves at least two difficulties. The first regards the inexistence of population-based studies, and the second regards the identification of its determinants given the potential effects of biological, socioeconomic, and behavioral factors, and factors related to the use of prenatal health care services $^{14}$.

The present study aimed to measure the prevalence and identify the factors associated with healthy gestational weight gain in parturient women from the municipality of Rio Grande, Rio Grande do Sul, in 2013.

\section{METHODS}

The municipality of Rio Grande has roughly 210,000 inhabitants. It is located in the southern coast of the state of Rio Grande do Sul, about $300 \mathrm{~km}$ from the state capital, Porto Alegre ${ }^{15}$. The present data stem from a population-based, cross-sectional study conducted in the only two maternity hospitals in Rio Grande between January 1 and December 31, 2013. The women were interviewed at the hospital within the first 48 hours after delivery. All women from the municipal urban or rural area who birthed a single child with a gestational age of at least 37 weeks were included.

The sample size was calculated based on a healthy gestational weight gain prevalence of $30.0 \%$, margin of error (or accuracy) of $2.5 \%$, confidence level of $95.0 \%$, and an extra $10.0 \%$ for eventual losses. Hence, the sample should include at least 1,411 parturient women. The prevalence of $30.0 \%$ used for calculating the sample size was an approximation of the percentages found by three Brazilian studies, one of them from the same state $e^{8,11,14}$. Regarding the identification of associated factors, the calculation that required a higher number of women used the following parameters: alpha level of 0.05 , beta level of 0.20 , non-exposed-to-exposed ratio of 14:96, outcome prevalence in non-exposed individuals of $26.0 \%$, and prevalence ratio of 1.4. Thus, this study should include at least 1,740 parturient women. This number already includes an additional 15.0 and $10.0 \%$ to control for potential confounders and losses, respectively.

Information was collected using a single coded questionnaire with a predominance of closed questions. Data from the prenatal care card, which contains data recorded during the prenatal care visits, were also collected and recorded in a standard form. Based on such data, the gestational age at birth was determined from the ultrasound scan performed between gestational weeks six and twenty as ultrasound scan is considered the most accurate method for estimating gestational age ${ }^{16,17}$. In the absence of this information, the study used the date of the last menstrual period recorded in the prenatal care card or that reported by the mother.

Gestational weight gain was given by subtracting the pregestational weight from the weight at the end of pregnancy. Healthy weight gain was defined as currently recommended by the $\mathrm{IOM}^{2}$, which establishes weight gain limits for each pregestational nutritional status category: from 12.5 to $18.0 \mathrm{~kg}$ for underweight women; from 11.5 to $16.0 \mathrm{~kg}$ for normal weight women; from 7.0 to $11.5 \mathrm{~kg}$ for overweight women; and from 5.0 to $9.0 \mathrm{~kg}$ for obese women.

The maternal pregestational nutritional status was classified according to the BMI, which divides the weight $(\mathrm{kg})$ by the square of the height $(m)$. This calculation was based on the pregestational weight and height recorded in the prenatal care card, measured no later than gestation week fourteen. If this information was not available, the study used the information reported by the woman during prenatal care or 
study interview. BMI $\left(\mathrm{kg} / \mathrm{m}^{2}\right)$ was classified as recommended by the World Health Organization ${ }^{18}$ : <18.5: underweight; 18.5 to 24.9: normal weight; 25.0 to 29.9: overweight; $\geq 30.0$ : obese. Weight at the end of pregnancy was collected from the prenatal care card (recorded up to ten days before parturition) or reported by the mother during the interview.

Four interviewers were selected and trained to perform the interviews. A pilot study was conducted a month earlier, at the beginning of data collection in the two maternity hospitals, to test the questionnaire and simulate real interview situations. The interviewees searched for the women using information recorded in the hospital records, then identified the woman in the maternity hospital and visited the wards. Only women who agreed to participate and signed two copies of a consent form, one of which remained with the mother, were interviewed.

The questions of each filled out questionnaire were coded, and the questionnaire was fully reviewed before digitization. The data were entered twice by different individuals in the freeware EpiData 3.1 (EpiData Association, Odense, Dermark), which verified consistency. The statistical analyses were then performed by the statistical software Stata version 13 (Stata Corporation, College Station, Texas, United States).

Descriptive analysis included measure of prevalence, mean, and standard deviation. The Chi-square test assessed whether pregestational $\mathrm{BMI}$ and healthy weight gain were associated. Poisson regression with adjusted robust variance performed the crude and adjusted analyses of healthy gestational weight gain with the independent variables. The $p$-value of the linear trend estimation was reported for the ordinal categorical variables 'education level' and 'parity', and the Wald test for heterogeneity was used for the other variables.

A four-level hierarchical model was used for the adjusted analysis of the factors associated with healthy weight gain for adjusting for possible confounders. The first level included demographic and socioeconomic variables; the second, environmental characteristics; the third, reproduction-related variables; and the forth, behavioral variables and variables related to prenatal and parturition care. Parity was defined as the number of live and stillbirths. Regular physical activity during pregnancy was noted, excluding activities of daily living. In the regression model (backwards), each variable was controlled for all variables in the same and preceding levels. All variables considered as important were kept in the model, even those with a $p$-value $>0.20$. The significance level was set at $5 \%$ for two-tailed tests.

Quality control consisted of repeating roughly $7 \%$ of the interviews by telephone. The index of agreement was calculated for 24 questions and varied from 0.61 for "reason for caesarian delivery" to 0.92 to "type of delivery". Most other questions presented an index of agreement in excess of 0.70 , which is considered satisfactory.

The research Protocol was approved by the Health Field Research Ethics Committee of the Universidade Federal do Rio Grande (Process $n^{\circ}$ 2623/2012-67).

\section{RES U L T S}

According to SINASC (Live Births Information System) and SIM (Mortality Information System), databases containing live and stillbirth statistics, women from the municipality of Rio Grande delivered 2,761 children in 2013. Of these, 2,685 mothers were interviewed, representing a response rate of $97.0 \%$. Given that this study included only single and term births, that is, at least 37 weeks of gestation, the study should have included 2,016 women. Since it was not possible to calculate the weight gain of 232 mothers either because they did not remember their weight or because this information was not noted in the prenatal care card, the final sample consisted of 1,784 parturient women, representing a final response rate of $88.5 \%$. 
The sample had a mean age and standard deviation of $26.2 \pm 6.5$ years, varying from 14 to 46 years. The median education level, income, and number of children were eleven years of formal education, $R \$ 1,800.00$, and two children (including the current pregnancy). Two-thirds of the sample was white, $32 \%$ had a family income of up to two minimum salaries per month, and $87 \%$ had a partner. About half the sample was primiparous, 40\% had planned the pregnancy, $89 \%$ attended six or more prenatal care visits, $80 \%$ attended the first prenatal care visit during the first trimester of pregnancy, $27 \%$ smoked, $34 \%$ practiced some kind of regular physical activity during pregnancy, and $60 \%$ of the gestational ages were estimated by ultrasound scan performed between the sixth and twentieth weeks of pregnancy (Table 1).

Table 2 shows that half the women were overweight at conception and $19.0 \%$ of these were obese; $31.6 \%$ had a healthy gestational weight gain; $31.8 \%$ had inadequate gestational weight gain; and $36.6 \%$ had excessive gestational weight gain. Underweight women at conception had the highest proportion of healthy weight gain $(p<0.001)$.

In adjusted analysis based on the hierarchical model (Table 3), only maternal education level and parity were significantly associated with healthy weight gain during pregnancy. Regarding maternal education level, the Prevalence Ratio (PR) was 1.78 (95\% Confidence Interval-95\% Cl=1.162.74) higher in women with 12 or more years of formal education than in women with 1 to 4 years of formal education. Primiparous women had a $\mathrm{PR}=1.35(95 \% \mathrm{Cl}=1.03-1.78)$ higher to gain a healthy amount of weight than women with three or more children.

\section{DISCUSSION}

One of every three women in the municipality had healthy weight gain during pregnancy. Underweight women at conception
Table 1. Demographic, socioeconomic, behavioral, and prenatal care-related characteristics of parturient women with single and term births (with a gestational age of at least 37 weeks) from the municipality of Rio Grande (RS), Brazil, in 2013.

\begin{tabular}{|c|c|c|}
\hline Variable & $n$ & $\%$ \\
\hline \multicolumn{3}{|l|}{ Age (in years) } \\
\hline 13 to 19 & 305 & 17.1 \\
\hline 20 to 24 & 482 & 27.0 \\
\hline 25 to 29 & 429 & 24.0 \\
\hline 30 or more & 568 & 31.9 \\
\hline \multicolumn{3}{|l|}{ Skin color } \\
\hline White & 1,205 & 67.5 \\
\hline Brown & 389 & 21.8 \\
\hline Black & 190 & 10.7 \\
\hline Live with partner & 1,559 & 87.4 \\
\hline \multicolumn{3}{|l|}{ Family income in quartiles } \\
\hline First (lowest) & 421 & 23.6 \\
\hline Second & 494 & 27.7 \\
\hline Third & 433 & 24.3 \\
\hline Fourth (highest) & 436 & 24.4 \\
\hline \multicolumn{3}{|l|}{ Education level (full years) } \\
\hline 1 to 4 & 101 & 5.7 \\
\hline 5 to 8 & 568 & 31.8 \\
\hline 9 to 11 & 818 & 45.9 \\
\hline 12 or more & 297 & 16.6 \\
\hline Employed during pregnancy & 805 & 45.1 \\
\hline \multicolumn{3}{|l|}{ Parity } \\
\hline 1 & 878 & 49.2 \\
\hline 2 & 553 & 31.0 \\
\hline 3 or more & 353 & 19.8 \\
\hline Planned pregnancy & 698 & 39.1 \\
\hline \multicolumn{3}{|l|}{ Trimester of first prenatal care visit } \\
\hline First & 1,426 & 80.0 \\
\hline Second & 335 & 18.8 \\
\hline Third & 22 & 1.2 \\
\hline Attended six or more prenatal care visits & 1,584 & 88.8 \\
\hline \multicolumn{3}{|l|}{ Self-reported conditions during pregnancy } \\
\hline Hypertension & 331 & 18,5 \\
\hline Diabetes & 82 & 4,6 \\
\hline Depression & 61 & 3,4 \\
\hline Bleeding & 81 & 4,5 \\
\hline \multicolumn{3}{|l|}{ Number of cigarettes smoked per day } \\
\hline None & 1,302 & 73.0 \\
\hline Up to nine & 121 & 6.8 \\
\hline Ten or more & 361 & 20.2 \\
\hline \multicolumn{3}{|l|}{ Physical activity during pregnancy } \\
\hline No & 1,172 & 65.7 \\
\hline Yes but quit & 174 & 9.7 \\
\hline Yes & 438 & 24.5 \\
\hline Total & 1,784 & 100.0 \\
\hline
\end{tabular}


Table 2. Healthy gestational weight gain based on maternal pregestational Body Mass Index (BMI). Rio Grande (RS), Brazil, 2013.

\begin{tabular}{lcccc}
\hline \multirow{2}{*}{ Pregestational BMI $\left(\mathrm{kg} / \mathrm{m}^{2}\right)(p<0.001)^{*}$} & $\mathrm{n}$ & $\%$ & $\mathrm{n}$ & Healthy weight gain \\
\hline Underweight $(<18.5)$ & & 46 & 36 & 41.9 \\
Normal weight (18.5-24.9) & 817 & 45.8 & 291 & 35.6 \\
Overweight (25.0-29.9) & 537 & 30.1 & 137 & 25.5 \\
Obese ( $\geq 30.0)$ & 344 & 19.3 & 100 & 29.1 \\
\hline Total & 1,784 & 100.0 & 564 & 31.6 \\
\hline
\end{tabular}

Note: ${ }^{*}$ Chi-square test.

Table 3. Crude and adjusted analyses for the factors associated with healthy gestational weight gain by women from the municipality of Rio Grande (RS), Brazil, 2013 ( $\mathrm{N}=1,784)$.

1 of 2

\begin{tabular}{|c|c|c|c|c|c|}
\hline \multirow{2}{*}{ Level } & \multirow{2}{*}{ Variable } & \multicolumn{2}{|c|}{ Prevalence of healthy weight gain } & \multicolumn{2}{|c|}{ Prevalence ratio $(95 \% \mathrm{Cl})$} \\
\hline & & $\%$ & $n$ & Crude & Adjusted \\
\hline \multirow[t]{24}{*}{$1^{\text {st }}$} & Age (in years) & & & $p=0.443$ & $p=0.645$ \\
\hline & 13 to 19 & 30.2 & 92 & 1.00 & 1.00 \\
\hline & 20 to 29 & 30.9 & 281 & $1.02(0.84-1.24)$ & $0.93(0.75-1.14)$ \\
\hline & 30 or more & 33.6 & 191 & $1.11(0.90-1.37)$ & $0.98(0.78-1.24)$ \\
\hline & Skin color & & & $p=0.290$ & $p=0.624$ \\
\hline & White & 32.8 & 395 & 1.00 & 1.00 \\
\hline & Brown & 29.8 & 116 & $0.90(0.76-1.08)$ & $0.94(0.79-1.12$ \\
\hline & Black & 27.9 & 53 & $0.85(0.67-1.08)$ & $0.90(0.71-1.15$ \\
\hline & Marital status & & & $p=0.223$ & $p=0.435$ \\
\hline & No partner & 28.0 & 63 & 1.00 & 1.00 \\
\hline & Has partner & 32.1 & 501 & $1.15(0.92-1.43)$ & $1.09(0.87-1.37)$ \\
\hline & Family income in quartiles & & & $p=0.025$ & $p=0.260$ \\
\hline & First (lowest) & 26.8 & 113 & 1.00 & 1.00 \\
\hline & Second & 33.6 & 166 & $1.25(1.02-1.53)$ & $1.19(0.97-1.46$ \\
\hline & Third & 29.8 & 129 & $1.11(0.90-1.37)$ & $1.01(0.80-1.27)$ \\
\hline & Fourth (highest) & 35.8 & 156 & $1.33(1.09-1.63)$ & $1.10(0.86-1.40)$ \\
\hline & Education level in full years & & & $p<0.001^{*}$ & $p=0.003^{*}$ \\
\hline & 1 to 4 & 20.8 & 21 & 1.00 & 1.00 \\
\hline & 5 to 8 & 28.5 & 162 & $1.37(0.92-2.05)$ & $1.39(0.92-2.08$ \\
\hline & 9 to 11 & 32.5 & 266 & $1.56(1.05-2.32)$ & $1.54(1.03-2.31)$ \\
\hline & 12 or more & 38.7 & 115 & $1.86(1.24-2.80)$ & $1.78(1.16-2.74$ \\
\hline & Employed during pregnancy & & & $p=0.091$ & $p=0.601$ \\
\hline & No & 29.9 & 293 & 1.00 & 1.00 \\
\hline & Yes & 33.7 & 271 & $1.12(0.98-1.29)$ & $1.04(0.98-1.22$ \\
\hline \multirow[t]{4}{*}{$2^{\text {nd }}$} & Number of household dwellers & & & $p=0.109$ & $p=0.335$ \\
\hline & 1 to 2 & 32.4 & 208 & 1.00 & 1.00 \\
\hline & 3 & 34.0 & 187 & $1.05(0.89-1.23)$ & $1.08(0.91-1.27)$ \\
\hline & 4 or more & 28.4 & 168 & $0.87(0.74-1.04)$ & $0.95(0.79-1.13$ \\
\hline \multirow[t]{4}{*}{$3^{\text {rd }}$} & Parity & & & $p=0.012^{*}$ & $p=0.029^{*}$ \\
\hline & 3 or more & 25.2 & 89 & 1.00 & 1.00 \\
\hline & 2 & 32.9 & 182 & $1.30(1.05-1.62)$ & $1.19(0.92-1.54$ \\
\hline & 1 & 33.4 & 293 & $1.32(1.08-1.63)$ & 1.35 (1.03-1.78) \\
\hline
\end{tabular}


Table 3. Crude and adjusted analyses for the factors associated with healthy gestational weight gain by women from the municipality of Rio Grande (RS), Brazil, $2013(\mathrm{~N}=1,784)$.

2 of 2

\begin{tabular}{|c|c|c|c|c|c|}
\hline \multirow{2}{*}{ Level } & \multirow{2}{*}{ Variable } & \multicolumn{2}{|c|}{ Prevalence of healthy weight gain } & \multicolumn{2}{|c|}{ Prevalence ratio $(95 \% \mathrm{Cl})$} \\
\hline & & $\%$ & $n$ & Crude & Adjusted \\
\hline \multirow[t]{3}{*}{$3^{\text {rd }}$} & Planned pregnancy & & & $p=0.025$ & $p=0.167$ \\
\hline & Yes & 34.7 & 242 & 1.00 & 1.00 \\
\hline & No & 29.6 & 322 & $0.86(0.75-0.98)$ & $0.90(0.78-1.04)$ \\
\hline \multirow[t]{27}{*}{$4^{\text {th }}$} & Trimester of first prenatal care visit & & & $p=0.104$ & $p=0.856$ \\
\hline & First & 32.8 & 468 & 1.00 & 1.00 \\
\hline & Second & 27.2 & 91 & $0.83(0.68-1.00)$ & $0.99(0.81-1.23)$ \\
\hline & Third & 22.7 & 5 & $0.33(0.30-0.35)$ & $0.80(0.37-1.73)$ \\
\hline & Prenatal care visits & & & $p=0.013$ & $p=0.104$ \\
\hline & Up to five & 23.5 & 47 & 1.00 & 1.00 \\
\hline & Six or more & 32.6 & 517 & $1.39(1.07-1.80)$ & $1.26(0.95-1.66)$ \\
\hline & Gestational hypertension & & & $p=0.025$ & $p=0.054$ \\
\hline & No & 32.8 & 477 & 1.00 & 1.00 \\
\hline & Yes & 26.3 & 87 & $0.80(0.66-0.97)$ & $0.82(0.69-1.00)$ \\
\hline & Gestational diabetes & & & $p=0.356$ & $p=0.294$ \\
\hline & No & 31.8 & 542 & 1.00 & 1.00 \\
\hline & Yes & 26.8 & 22 & $0.92(0.76-1.10)$ & $0.90(0.75-1.09)$ \\
\hline & Gestational depression or psychiatric condition & & & $p=0.036$ & $p=0.084$ \\
\hline & No & 32.1 & 553 & 1.00 & 1.00 \\
\hline & Yes & 18.0 & 11 & $0.75(0.57-0.98)$ & $0.78(0.59-1.03)$ \\
\hline & Gestational bleeding & & & $p=0.264$ & $p=0.067$ \\
\hline & No & 31.4 & 543 & 1.00 & 1.00 \\
\hline & Yes & 37.0 & 30 & $1.08(0.94-1.26)$ & $1.14(0.99-1.31)$ \\
\hline & Number of cigarettes smoked per day & & & $p=0.013$ & $p=0.172$ \\
\hline & None & 33.6 & 437 & 1.00 & 1.00 \\
\hline & Up to nine & 29.7 & 36 & $0.89(0.67-1.18)$ & $0.93(0.70-1.23)$ \\
\hline & Ten or more & 25.2 & 91 & $0.75(0.62-0.91)$ & $0.83(0.68-1.01)$ \\
\hline & Physical activity during pregnancy & & & $p=0.172$ & $p=0.192$ \\
\hline & No & 30.4 & 356 & 1.00 & 1.00 \\
\hline & Yes and quit & 31.0 & 54 & $1.02(0.80-1.30)$ & $0.97(0.77-1.24)$ \\
\hline & Yes & 35.2 & 154 & $1.16(0.99-1.35)$ & $1.14(0.98-1.33)$ \\
\hline
\end{tabular}

Note: *Test for linear trend.

had a higher proportion of healthy weight gain. The probability of healthy weight gain also increased with education level and smaller number of children.

This study found a high frequency of unhealthy (excessive or inadequate) weight gain during pregnancy. The association between inadequate gestational weight gain, low birth weight, and prematurity is widely known ${ }^{3,11}$. Excessive gestational weight gain increases the odds of large-for-gestational-age infants, gestational hypertension, caesarian delivery, and postpartum weight retention. Inadequate and excessive weight gain are independently associated with a higher risk of childhood obesity ${ }^{19}$. Since weight gain is a modifiable risk factor, its deviations could be identified and corrected during pregnancy. Hence, promotion of healthy weight gain can be an important element to avoid adverse maternal and fetal outcomes. 
Healthy gestational weight gain found in one-third of the sample is in agreement with other Brazilian and foreign studies $3,9,11$. These studies demonstrate the tendency of healthy weight gain to decrease as excessive weight gain increases, which in the present study affected $36.6 \%$ of the sample. These data are in agreement with the current nutritional transition in Brazil, with a growing prevalence of excess weight ${ }^{20}$. Additionally, there is a simultaneous concern with inadequate weight gain $(31.8 \%)$. However, the study underweight women at conception presented the highest frequency of healthy weight gain. This demonstrates a higher propensity for gestational weight gain also in these women, or the result of more assistance and care to this group. Drehmer et al. ${ }^{8}$ reported that prenatal care focuses on inadequate weight gain to avoid low birth weight, and less attention is given to excessive weight gain. Therefore, although inadequate weight gain persists as a health problem, excessive weight gain is an issue that demands priority.

Two multicentric cohort studies were found on gestational weight gain in Brazil. In six Brazilian capitals, Nucci et al. ${ }^{21}$ found 29 and 33\% prevalences of excessive and healthy gestational weight gain, respectively. However, they used the 1990 IOM to assess weight gain. In these same capitals and using the current IOM guidelines, Drehmer et al. ${ }^{11}$ found 33 and 34\% prevalences of excessive and healthy gestational weight gains, respectively. In a cohort of 667 women from two cities in Rio Grande do Sul, the percentages of excessive and healthy gestational weight gains reached 45 and $29 \%$, respectively ${ }^{8}$. The study results suggest a discrete deterioration in the prevalence of healthy gestational weight gain in the Brazilian South.

The poor nutritional status of many women at conception is also worthy of mention. Pregestational BMl showed that $49.4 \%$ of the women were overweight or obese at conception, and one of every five was obese at conception. The former percentage was much higher than the $28.7 \%$ of excess weight found by Drehmer et al. ${ }^{11}$ in six Brazilian capitals. Women with excess weight are about twice as likely to gain too much weight during pregnancy as normal weight women at conception ${ }^{22}$. It is estimated that $70.0 \%$ of all obese women after delivery became obese during pregnancy. Thus, pregnancy is considered a risk for obesity in women of childbearing age ${ }^{23}$.

Differences in maternal characteristics seem to influence gestational weight gain, and among them, education level seems to be a determinant. Higher education levels in the study women were associated with higher probabilities of healthy weight gain. Higher education levels provide more information and understanding of the criteria required for making healthier food choices $^{24}$. In addition to a better balanced diet, these women are more active and likely to have better life habits. These facts contribute to a healthier gestational weight gain by women with higher education levels.

Regarding the influence of parity on weight gain, some studies have found that having one or more children makes women more likely to be overweight and three to four times more likely to become obese in the first five years that follow delivery than childless women ${ }^{25}$. This study found that the probability of healthy weight gain increases as the number of pregnancies decreases. According to Melzer \& Schutz ${ }^{26}$, each successive birth adds on average $1 \mathrm{~kg}$ of postpartum weight in excess of what is normally gained with age. Hence, women with higher parities would proportionally have higher body weight, facilitating excessive weight gain during pregnancy.

The study women with gestational hypertension had borderline significance for healthy weight gain. Studies with larger sample sizes would be necessary to better clarify this relationship. Excess body weight is an established risk factor for high blood pressure. Some longitudinal studies found that gestational hypertension is more likely to occur in women who had excess weight at conception and who 
gain weight abusively ${ }^{4,27}$. Since half the women presented this risk factor at conception, the study result may have been affected by reverse causality bias, since it is difficult to determine whether hypertension preceded or stemmed from excess weight. However, women with gestational hypertension are more likely to experience edema than those with normal blood pressure, and edema may promote more gestational weight gain and consequently, a smaller chance of healthy weight gain².

Given the small proportion of women with healthy weight gain, especially in comparison with those with excessive weight gain, nutritional interventions are necessary in this population. According to Tovar ${ }^{13}$, women who were advised during pregnancy and those compliant with the IOM guidelines are more likely to have healthy weight gain. Additionally, behavioral and educational interventions in women who are normal weight at conception may reduce excessive weight gain by about $40 \%{ }^{28}$.

Primary health care services seem to pay little attention to the monitoring of gestational weight gain ${ }^{11}$. Although the vast majority of the study gravidas attended six or more prenatal care visits from the first trimester of pregnancy, this service was incapable of promoting a healthy gestational weight gain. In Rio de Janeiro, Niquini et al. ${ }^{29}$ studied nutritional care during pregnancy provided by seven family health care units and found that little attention was given to the assessment and monitoring of the women's nutritional status and weight gain. This study found that most women had no access to a dietitian during prenatal care visits for nutritional care. Only one of 149 women who received nutritional care during pregnancy received it from a dietitian. And only $28.3 \%$ of the women received correct information about their gestational weight gain, while $90.7 \%$ did not have their gestational weight measured during the visits and recorded in the cards (nothing was noted in the graph BMI/ gestational week). This fact suggests that many women have unhealthy weight gain during pregnancy because of inadequate weight monitoring.

Given the study results, some limitations may have affected the study: 1) a cross-sectional design is not the most appropriate design to study causality because it measures exposure and outcomes simultaneously. However, given its short duration and low cost, and especially that the associations found herein had already been identified in cohort studies, the present study provides valuable data for mother/child health care policies; and 2) low reliability of the selfreported anthropometric measurements. A validation study of anthropometric data conducted in a similar population from Pelotas $(\mathrm{RS})^{30}$, found that these differences are small (selfreported BMI coincided with the measured BMI in $86 \%$ of the women), and since it did not substantially affect the result, the use of selfreported data is justified. Moreover, many studies rely on self-reported information ${ }^{4,9}$, which facilitates result comparison. Finally, the agreement between the reported and measured weights in the present study were tested by Lin's Concordance Correlation Coefficient, which was $0.973(95 \% \mathrm{Cl}=0.969-0.976)$ for pre-pregnancy weight and $0.990(95 \% \mathrm{Cl}=0.988-0.991)$ for the weight at the end of pregnancy. In both cases, the study estimates had good or excellent approximation.

\section{CONCLUSION}

The study found a small proportion of women with healthy weight gain during pregnancy, mainly in relation to excessive weight gain. Despite its wide availability, prenatal care seems to have little impact on weight at the end of pregnancy, suggesting the need of better monitoring and nutritional counseling during pregnancy. Women who are overweight at conception, have low education level, and have had multiple pregnancies require special attention. For unmodifiable pregnancy factors, an approach focusing on women's health, education, and healthy life habits is also expedient. 


\section{COLABORATIONS}

LP MARMITT development of research project, data analysis, and article writing. CV GONÇALVES helped to develop the research project and write the article. JA CÉSAR helped to develop the research project, supervised data collection, digitization, and analysis, and reviewed the article.

\section{REFERENCES}

1. Rode L, Kjærgaard H, Ottesen B, Damm P, Hegaard HK. Association between gestational weight gain according to body mass index and postpartum weight in a large cohort of danish women. Matern Child Health J. 2012; 16(2):406-13. http://dx.doi. org/10.1007/s10995-011-0775-z

2. Institute of Medicine. Weight gain during pregnancy. Reexamining the guidelines. Prepublication copy: Uncorrected proofs. Washington (DC): National Academics Press; 2009.

3. Heaman M, Kingston D, Chalmers B, Sauve R, Lee $L$, Young D. Risk factors for preterm birth and smallfor-gestational-age births among canadian women: Risk factors for PTB and SGA births. Paediatr Perinat Epidemiol. 2013; 27(1):54-61. http://dx.doi.org/10. 1111/ppe.12016

4. Johnson J, Clifton RG, Roberts JM, Myatt L, Hauth JC, Spong CY, et al. Pregnancy outcomes with weight gain above or below the 2009 Institute of Medicine Guidelines. Obstet Gynecol. 2013; 121(5):969-75. http://dx.doi.org/10.1097/AOG. Ob013e31828aea03

5. Li N, Liu E, Guo J, Pan L, Li B, Wang P, et al. Maternal Prepregnancy Body mass index and gestational weight gain on pregnancy outcomes. PLoS One. 2013; 8(12):e82310. http://dx.doi.org/10.1371/ journal.pone.0082310

6. Moore Simas TA, Doyle Curiale DK, Hardy J, Jackson $S$, Zhang $Y$, Liao $X$. Efforts needed to provide Institute of Medicine-recommended guidelines for gestational weight gain. Obstet Gynecol. 2010; 115(4):777-83. http://dx.doi.org/10.1097/AOG. Ob013e3181d56e12

7. Kent E, O'Dwyer V, Fattah C, Farah N, O'Connor C, Turner MJ. Correlation between birth weight and maternal body composition. Obstet Gynecol. 2013; 121(1):46-50.

8. Drehmer M, Camey S, Schmidt MI, Olinto MT, Giacomello, Buss C, et al. Socioeconomic, demographic and nutritional factors associated with maternal weight gain in general practices in Southern Brazil. Cad Saúde Pública. 2010; 26:1024-34.
9. Kowal C, Kuk J, Tamim H. Characteristics of weight gain in pregnancy among Canadian women. Matern Child Health J. 2012; 16(3):668-76. http:// dx.doi.org/10.1007/s10995-011-0771-3

10. Munim S, Maheen H. Association of gestational weight gain and pre-pregnancy body mass index with adverse pregnancy outcome. J Coll Physicians Surg Pak. 2012; 22:694-98.

11. Drehmer M, Duncan BB, Kac G, Schmidt MI. Association of second and third trimester weight gain in pregnancy with maternal and fetal outcomes. Frasch. PLoS One. 2013; 8(1):e54704. http://dx.doi.org/10.1371/journal.pone.0054704

12. Bogaerts A, Van den Bergh B, Nuyts $E$, Martens $E$, Witters I, Devlieger R. Socio-demographic and obstetrical correlates of pre-pregnancy body mass index and gestational weight gain: Correlates of pre-pregnancy BMI and GWG. Clin Obes. 2012; 2(5-6):150-9. http://dx.doi.org/10.1111/cob.12004

13. Tovar A, Guthrie LB, Platek D, Stuebe A, Herring SJ, Oken E. Modifiable predictors associated with having a gestational weight gain goal. Matern Child Health J. 2011; 15(7):1119-26. http://dx.doi.org/ 10.1007/s10995-010-0659-7

14. Marano D, da Gama SGN, Pereira APE, Souza Junior PRB. Adequacy of weight gain in pregnant women from two municipalities of Rio de Janeiro state (RJ), Brazil, 2008. Rev Bras Ginecol Obstet. 2012; 34(8):386-93.

15. Instituto Brasileiro de Geografia e Estatística. Estimativas da população residente nos municípios brasileiros com data de referência em 1 de julho de 2014. Rio de Janeiro: IBGE; 2014 [acesso 2015 jan 20]. Disponível em: http://www.ibge.gov.br/ home/estatistica/populacao/estimativa2014

16. National Institute for Health and Care Excellence. Antenatal care: Routine care for the healthy pregnant woman. London: National Institute for Health Care Excellence; 2008.

17. Pereira APE, Leal MC, da Gama SGN, Domingues RMSM, Schilithz AOC, Bastos MH. Determinação da idade gestacional com base em informações do estudo Nascer no Brasil. Cad Saúde Pública. 2014; 30:S59-S70. http://dx.doi.org/10.1590/0102-311X 00160313

18. World Health Organization. Physical status: The use and interpretation of anthropometry. Report of a WHO Expert Committee. World Health Organ Tech Rep Ser. 1995; 854:1-452.

19. Oken E. Maternal and child obesity: The causal link. Obstet Gynecol Clin North Am. 2009; 36(2):361-77. http://dx.doi.org/10.1016/j.ogc.2009.03.007

20. Ramos L, Pereira MLC, Mota MA, Jacob T, Nakaoka VY, Kashibawakara V. A transição da desnutrição 
para a obesidade. Braz J Surg Clin Res. 2014; 5(1):64-8.

21. Nucci LB, Duncan BB, Mengue SS, Branchtein L, Schmidt MI, Fleck ET. Assessment of weight gain during pregnancy in general prenatal care services in Brazil. Cad Saúde Pública. 2001; 17(6):1367-74.

22. Chu SY, Callaghan WM, Bish $C L$, D'Angelo D. Gestational weight gain by body mass index among US women delivering live births, 2004-2005: Fueling future obesity. Am J Obstet Gynecol. 2009; 200(3):271e1-7. http://dx.doi.org/10.1016/j.ajog. 2008.09.879

23. Davis RR, Hofferth SL. The association between inadequate gestational weight gain and infant mortality among U.S. infants born in 2002. Matern Child Health J. 2012; 16(1):119-24. http://dx.doi. org/10.1007/s10995-010-0713-5

24. Larrañaga I, Santa-Marina L, Begiristain H, Machón $M$, Vrijheid $M$, Casas $M$, et al. Socio-economic inequalities in health, habits and self-care during pregnancy in Spain. Matern Child Health J. 2013; 17(7):1315-24. http://dx.doi.org/10.1007/s1099 5-012-1134-4

25. Davis EM, Zyzanski SJ, Olson CM, Stange KC, Horwitz RI. Racial, ethnic, and socioeconomic differences in the incidence of obesity related to childbirth. Am J Public Health. 2009; 99(2):294.
26. Melzer K, Schutz Y. Pre-pregnancy and pregnancy predictors of obesity. Int J Obes. 2010; 34(Suppl. 2):S44-52. http://dx.doi.org/10.1038/ijo.2010.239

27. Macdonald-Wallis C, Tilling K, Fraser A, Nelson SM, Lawlor DA. Gestational weight gain as a risk factor for hypertensive disorders of pregnancy. Am J Obstet Gynecol. 2013; 209(4):327.e1-327.e17. http://dx.doi.org/10.1016/j.ajog.2013.05.042

28. Phelan S, Phipps MG, Abrams B, Darroch F, Schaffner A, Wing RR. Randomized trial of a behavioral intervention to prevent excessive gestational weight gain: The Fit for Delivery Study. Am J Clin Nutr. 2011; 93(4):772-9. http://dx.doi. org/10.3945/ajcn.110.005306

29. Niquini RP, Bittencourt SA, Lacerda EMA, Saunders C, Leal MC. Avaliação do processo da assistência nutricional no pré-natal em sete unidades de saúde da família do Município do Rio de Janeiro. Ciênc Saúde Colet. 2012; 17(10):2805-16.

30. Da Silveira EA, Araújo CL, Gigante DP, Barros AJ, Lima MS. Validação do peso e altura referidos para o diagnóstico do estado nutricional em uma população de adultos no Sul do Brasil. Cad Saúde Pública. 2005; 21(1):235-45.

Received: July 7, 2015

Final version: November 9, 2015

Approved: February 23, 2016 
